\title{
Verification of the Stormwater Drainage System Overloads in Wrocław for an Assessment of Climate Change Effects
}

\author{
Monika Nowakowska1, Katarzyna Wartalska1', Bartosz Kaźmierczak¹, Andrzej Kotowski \\ 1 Faculty of Environmental Engineering, \\ Wroclaw University of Science and Technology, \\ 27 Wybrzeże Wyspiańskiego Street, 50-370 Wrocław, Poland \\ * Corresponding author, e-mail: monika.nowakowska@pwr.edu.pl
}

Received: 11 June 2018, Accepted: 11 January 2019, Published online: 13 February 2019

\begin{abstract}
This paper presents a verification of the performance of the stormwater drainage system in Gaj and Tarnogaj residential developments in Wrocław with regard to climate changes, by means of a calibrated hydrodynamic model created within the SWMM software. The verification was carried out for two criterial rainfalls: the Euler model rainfall with occurrence frequency $C=3$ years and an actual rainfall with $C=5$ years. Two parameters: degree of flooding (DOF) and specific flood volume (SFV) were adopted to indicate potential system overloads. The simulations showed numerous outflows from the sewers, which means, that the investigated system needs adapting to climate changes. The causes of this should be sought in the too small diameters of the sewers and so in the insufficient hydraulic capacity of the sewerage system dimensioned in the past using methods which are inadequate today.
\end{abstract}

\section{Keywords}

urban hydrology, rainwater, hydrodynamic modelling, stormwater management model

\section{Introduction}

Because of the random character of precipitation, the operation of stormwater drainage or combined sewer systems cannot be entirely reliable. Extreme natural phenomena (intensifying in recent years), such as torrential or persistent rains, and the resulting urban floods cause substantial economic losses [1-2]. According to EN 752, efforts should be made to achieve the currently required water drainage standard for urban areas, defined as the adaptation of the drainage system to receiving the maximum (forecasted) rainfall water streams occurring with a frequency equal to the allowable (socially acceptable) frequency of occurrence of a terrain surface flooding (Table 1 and Table 2).

Table 1 Recommended frequency of designed computational rain and limit the frequency of spill in accordance with EN 752:2008

\begin{tabular}{lcc}
\hline $\begin{array}{l}\text { Design rainfall } \\
\text { frequency }\end{array}$ & $\begin{array}{c}\text { The area drainage standard } \\
\text { category }\end{array}$ & $\begin{array}{c}\text { Flooding occurrence } \\
\text { frequency }\end{array}$ \\
\hline 1 per 1 year & $\begin{array}{c}\text { Rural areas } \\
\text { Residential areas } \\
1 \text { per 2 years }\end{array}$ & $\begin{array}{c}1 \text { per } 10 \text { years } \\
1 \text { per } 20 \text { years }\end{array}$ \\
1 per 5 years & $\begin{array}{c}\text { City centres/industrial/ } \\
\text { commercial areas }\end{array}$ & 1 per 30 years \\
1 per 10 years & $\begin{array}{c}\text { Underground railway/ } \\
\text { underpasses }\end{array}$ & 1 per 50 years \\
\hline
\end{tabular}

Table 2 Examples of design sewer flooding criteria for standing floodwater in accordance with EN 752:2017

\begin{tabular}{|c|c|c|}
\hline Impact & Example locations & Return period* \\
\hline Very low & $\begin{array}{c}\text { Roads or open spaces away from } \\
\text { buildings }\end{array}$ & 1 per 1 year \\
\hline Low & $\begin{array}{l}\text { Agricultural land (depending on } \\
\text { land use, e.g. pasture, arable) }\end{array}$ & 1 per 2 years \\
\hline Low to medium & $\begin{array}{l}\text { Open spaces used for public } \\
\text { amenity }\end{array}$ & 1 per 3 years \\
\hline Medium & $\begin{array}{c}\text { Roads or open spaces adjacent } \\
\text { to buildings }\end{array}$ & 1 per 5 years \\
\hline Medium to high & $\begin{array}{l}\text { Flooding in occupied buildings } \\
\text { excluding basements }\end{array}$ & 1 per 10 years \\
\hline High & $\begin{array}{c}\text { Deep flooding in occupied } \\
\text { basements or road underpasses }\end{array}$ & 1 per 30 years \\
\hline Very high & Critical infrastructure & 1 per 50 years \\
\hline
\end{tabular}

* Return period should be increased (probabilities reduced) where the floodwater is fast moving. When undertaking rehabilitation of existing systems and where achieving the same design criteria for a new system would entail an excessive cost, a lower value may be considered.

Stormwater sewers should have such diameters that their total capacity will always be greater than the design runoff (Table 1). But the dependence between the frequency of the assumed rainfall and the flooding frequency (Table 
1 and Table 2) cannot be generalized since the description of the motion of the liquid in sewers is nonlinear. The dependence can be determined only through the hydrodynamic modelling of a given sewerage system. German recommendations DWA-A118 of 2006, introducing the concept of the frequency of surcharging up to the ground level in sewerage system performance check calculations (Table 3), can be helpful in this regard. Then in an indirect way one can determine the overload state closest to the subsequent flooding. A serious flooding hazard will occur when water exceeds the level of street kerbs and enters the adjacent properties, the basements of the buildings, etc.

Considering the current knowledge of the future trends in climate change [3-9], the design rainfalls can be adjusted to terrain drainage dimensioning (Table 1 and Table 3) by correcting the current rainfall intensities or by changing the frequencies of their occurrence in the future. In [10] it was shown that today's rainfall events with a statistical repeatability of, e.g., five years, in the future will be events with a frequency of occurrence $C=2$ years. Therefore a scenario of rainfalls with $C=5$ years instead of $C=3$ years is recommended for verifying the occurrence of future surcharging events in housing areas and a scenario of precipitation with $C=100$ years is recommended to ensure the currently allowable flooding frequency of once every 20 years (Table 4).

A considerable number of stormwater drainage systems in Poland was dimensioned using rainfalls intensity formulas which are inadequate today. As a result, the systems are likely to be unable to meet the requirements concerning the allowable frequency of sewer overflows (especially in the future) $[12,13]$.

This paper presents a verification of the stormwater drainage system performance in Gaj and Tarnogaj residential developments in Wrocław for the present and forecasted future rainfalls.

\section{Model drainage area and research methodology}

A hydrodynamic model of the stormwater drainage system, created within the SWMM software, was used for this study. The drainage area is $F=104$ ha. The main stormwater sewer (KD1) network consists of concrete sewers $0.30-1.20 \mathrm{~m}$ in diameter. The total length of the sewers amounts to about $17730 \mathrm{~m}$ and the number of manholes to 509 . Seventy five drainage sub-catchments were distinguished in the model [14].

Calibration of the hydrodynamic model included the following hydraulic and hydrological parameters: roughness coefficient of the sewer's interior, roughness coefficient
Table 3 Recommended frequencies for calculations testing the stormwater drainage performance in accordance with DWA-A118:2006

\begin{tabular}{lcc}
\hline $\begin{array}{l}\text { Design rainfall } \\
\text { frequency }\end{array}$ & $\begin{array}{c}\text { The area drainage } \\
\text { standard category }\end{array}$ & $\begin{array}{c}\text { Acceptable } \\
\text { surcharging frequency }\end{array}$ \\
\hline 1 per 1 year & Rural areas & 1 per 2 years \\
1 per 2 years & Residential areas & 1 per 3 years \\
& City centres/industrial/ & Less than \\
1 per 5 years & commercial areas & 1 per 5 years \\
& Underground railway/ & Less than \\
1 per 10 years & underpasses & 1 per 10 years* \\
\hline
\end{tabular}

* When local security measures are not applied, then: „1 per 50”

Table 4 Recommended changes in rainfall frequency for identification of future sewage systems overloads [11]

\begin{tabular}{lcc}
\hline $\begin{array}{l}\text { The area drainage } \\
\text { standard category }\end{array}$ & $\begin{array}{c}\text { Design rainfall } \\
\text { frequency for } \\
\text { overloads verification } \\
{[1 \text { per } C \text { years }]}\end{array}$ & $\begin{array}{c}\text { Design rainfall } \\
\text { frequency for } \\
\text { floodings verification } \\
{[1 \text { per } C \text { years }]}\end{array}$ \\
\hline $\begin{array}{l}\text { Rural areas } \\
\text { Residential areas }\end{array}$ & 5 instead of 2 & 50 instead of 10 \\
$\begin{array}{l}\text { City centres/ } \\
\text { industrial/ } \\
\text { commercial areas } 3\end{array}$ & 100 instead of 20 \\
\hline
\end{tabular}

of runoff area, depth of depression storage, and hydraulic width of the overland flow path. For the calibration and validation of the model, rainfall data from the two-year observation period (5 precipitation for calibration and 3 for validation), with the amounts from 9.7 to $28.4 \mathrm{~mm}$ and durations from 42 to 1486 minutes were used. The rain gauge, from which rainfall data were applied, is located only 620 $\mathrm{m}$ from the center of gravity of the analyzed catchment. The aim of the calibration was to achieve the highest possible compliance between simulated and measured values for the runoff volume balance.

Two parameters: degree of flooding $(D O F)$ and specific flood volume $(S F V)$ were adopted to indicate potential system overloads.

$D O F=\sum N_{f} / \sum N$

where:

$N_{f}$ - number of flooded manholes,

$N$ - total number of manholes.

$S V F=\sum F V / \sum S S$

where:

FV - flood volume, $\mathrm{m}^{3}$,

SS - sealed surface, ha.

The limit values of parameters (1) and (2) should be set individually. For example in [15], for three sewerage systems in North Rhine-Westphalia, the limit values of the parameters were determined to be: $D O F=0.33$ and $S F V=13 \mathrm{~m}^{3} / \mathrm{ha}$. 
The Euler model rainfall type II with occurrence frequency $C=3$ years and an intensive rainfall (of 19.07.2015) with the frequency of occurrence in Wrocław $C=5$ years were assumed as the drainage area load for respectively the current supply conditions and the future supply conditions.

The model rainfalls are synthetic rainfall histograms created on the basis of local formulas for rainfall depth-duration-frequency $(D D F)$ or intensity-duration-frequency $(I D F)$. In the hydrological conditions of Wrocław, the $D D F$ model is applied. The model has the form:

$h=-4.58+7.41 t^{0.242}+\left(9711 t^{0.0 .222}-98.68\right)(-\ln p)^{0.809}$

where:

$h$ - precipitation amount, $\mathrm{mm}$,

$t$ - precipitation duration, $\mathrm{min}$,

$p$ - occurrence probability, $p=1 / C$.

The idea of the model is to most closely represent the pattern of typical rainfalls characterized by time-variable intensity. An example here is the Euler model rainfall type II recommended by DWA-A118:2006 for modelling sewerage in Germany, and also in Poland [12, 17].

\section{Verification of overloads for model rainfall}

In order to verify the occurrence of surcharging in sewers in accordance with DWA-A 118:2006 one should load the investigated residential development drainage area with rainfall with occurrence frequency $C=3$ years and duration at least twice longer than the time of the flow in the network. Since in main sewer KD1 this time amounted to 45 minutes, the Euler model rainfall for $t=90 \mathrm{~min}$ and $C=3$ years was adopted. Fig. 1 shows the main sewer profile with the maximum overloads.

In the simulation instant shown in Fig. 1 , at $2 / 3$ of the length of main sewer KD1 sewage flows under pressure. Several critical points with up to the ground level surcharges, and floodings occur along the route of KD1. In this

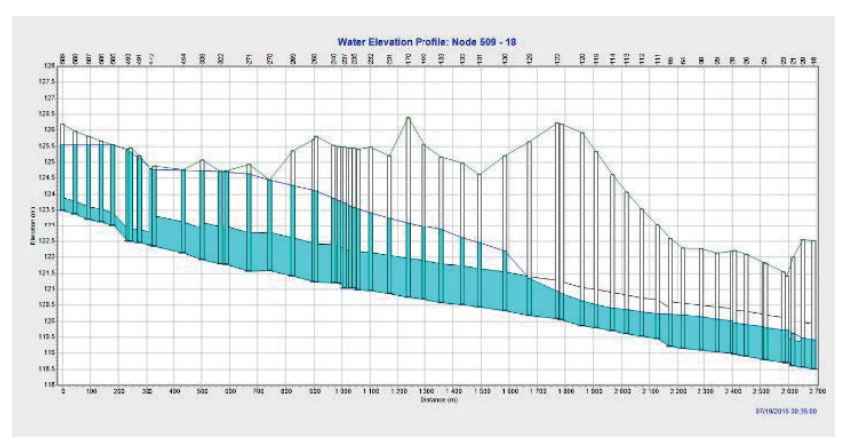

Fig. 1 KD1 trunk sewer operation at 35th minute of Euler model rainfall duration
Table 5 Localizations and volumes of floodings from stormwater drainage for Euler type II model rainfall

\begin{tabular}{lccc}
\hline Node & $\begin{array}{c}\text { Hours } \\
\text { flooding, }\end{array}$ & $\begin{array}{c}\text { Time of flooding } \\
\text { occurrence, h:min }\end{array}$ & $\begin{array}{c}\text { Flooding volume, } \\
\mathrm{m}^{3}\end{array}$ \\
\hline 423 & 0.41 & $00: 35$ & 481 \\
75 & 0.37 & $00: 35$ & 254 \\
99 & 0.36 & $00: 35$ & 232 \\
45 & 0.50 & $00: 35$ & 204 \\
$238 \mathrm{z}$ & 0.45 & $00: 37$ & 196 \\
168 & 0.82 & $00: 45$ & 195 \\
427 & 0.51 & $00: 35$ & 176 \\
270 & 0.14 & $00: 37$ & 164 \\
80 & 0.29 & $00: 35$ & 160 \\
43 & 0.21 & $00: 35$ & 158 \\
47 & 0.84 & $00: 48$ & 146 \\
103 & 0.59 & $00: 28$ & 118 \\
456 & 0.22 & $00: 32$ & 117 \\
430 & 0.28 & $00: 35$ & 111 \\
\hline
\end{tabular}

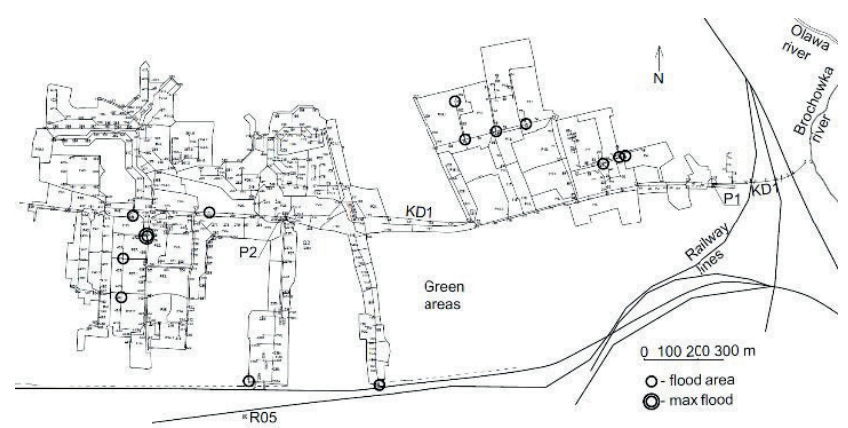

Fig. 2 Localization of floodings from stormwater drainage system for Euler model rainfall type II for $C=3$ years and $t=90$ minutes

study, it was assumed that outflows with a volume of over $100 \mathrm{~m}^{3}$ can pose potential hazards. Then assuming the water height to be at the level of pavement kerbs $(0.15 \mathrm{~m})$, the inundation would cover an area larger than $25 \mathrm{~m} \times 25 \mathrm{~m}=$ $625 \mathrm{~m}^{2}$, which corresponds to a typical drainage gully spacing of $25 \mathrm{~m}$ [12]. There are 14 such nodes in the investigated network (Table 5). In the analysis of surface flooding, the default SWMM program settings were used in this area - no special methods were used.

The longest duration (about 50 minutes) outflows occurred in nodes no. 47 and 168 (with a volume of 146 and $195 \mathrm{~m}^{3}$, respectively). An extremely large outflow volume, amounting to $481 \mathrm{~m}^{3}$ and lasting for 25 minutes, was found to occur in the node no. 423 area.

Fig. 2 shows the locations of the 14 areas in which sewerage surcharges and substantial floodings occur.

The indicators: $D O F$ and $S F V$ were used to describe the overload of the system. They were calculated from formulas (1) and (2) to amount to: $D O F=0.16\left(N_{f}=79, N=509\right)$ and 
$S F V=44.1 \mathrm{~m}^{3} / \mathrm{ha}\left(F V=2712 \mathrm{~m}^{3}, S S=61.5 \mathrm{ha}\right)$. According to the criteria in [15], $D O F<0.33$, while $S F V>13 \mathrm{~m}^{3} /$ ha indicates the system should be upgraded right now.

\section{Verification of overloads for actual rainfall}

The actual rainfall of 19.07.2015 was used to verify the performance of the sewerage system in climate change conditions. The rainfall histogram for five minute time intervals is shown in Fig. 3.

Fig. 4 shows the KD1 main sewer profile at the 20th minute of rainfall duration, i.e. when the maximum overloads occur. At this instant at 2/3 of the length of trunk sewer KD1 the sewage flows under pressure (similarly as for the Euler model rainfall type II). There are numerous critical points where storm sewage reaches the ground level.

For the rainfall with $C=5$ years, floodings in 17 nodes (Table 6) can pose potential hazards. Similarly, as in the case of the Euler model rainfall, the longest lasting (about $30 \mathrm{~min}$ ) flooding in the network occurred in 2 critical nodes: no. 47 and 168. The largest simulated outflow volumes occurred in 8 nodes.

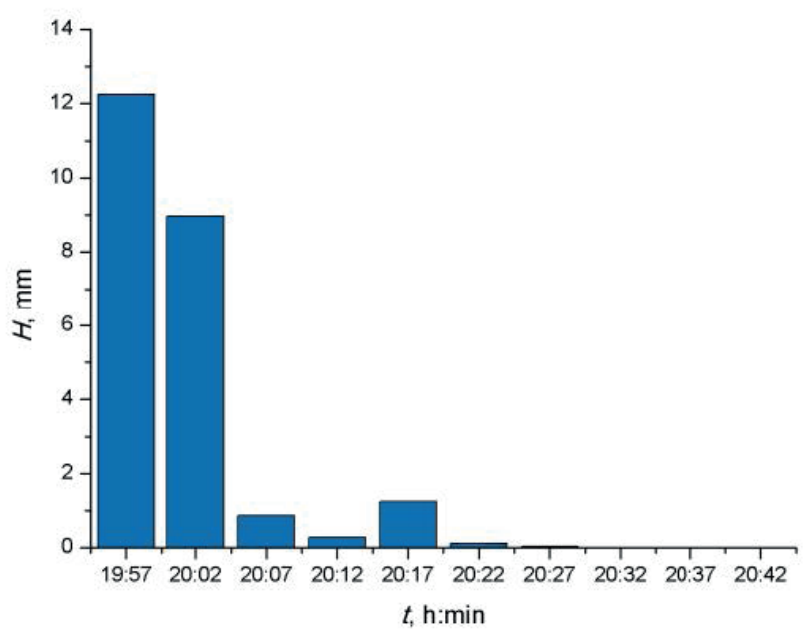

Fig. 3 Actual rainfall histogram of 19.07.2015 with $C=5$ years and $t=42$ minutes

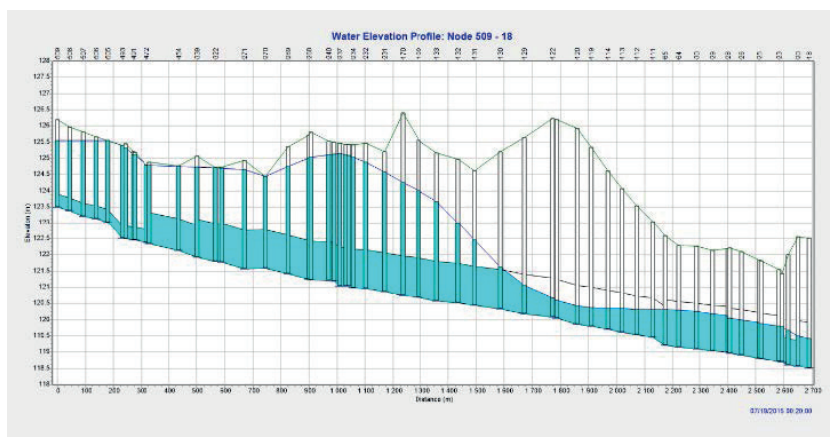

Fig. 4 Profile of the KD1 main sewer at 20th minute of actual rainfall duration with $C=5$ years and $t=42$ minutes
Table 6 Localizations and volumes of floodings from stormwater drainage for actual rainfall

\begin{tabular}{|c|c|c|c|}
\hline Node & $\begin{array}{c}\text { Hours } \\
\text { flooding, } \mathrm{h}\end{array}$ & $\begin{array}{l}\text { Time of flooding } \\
\text { occurrence, h:min }\end{array}$ & $\begin{array}{l}\text { Flooding volume, } \\
\mathrm{m}^{3}\end{array}$ \\
\hline 423 & 0.38 & 00:19 & 515 \\
\hline 75 & 0.35 & 00:20 & 359 \\
\hline 99 & 0.37 & 00:20 & 354 \\
\hline 43 & 0.25 & 00:20 & 327 \\
\hline 270 & 0.17 & $00: 22$ & 299 \\
\hline 45 & 0.43 & 00:20 & 272 \\
\hline 80 & 0.28 & $00: 20$ & 262 \\
\hline 427 & 0.42 & 00:20 & 253 \\
\hline 430 & 0.25 & $00: 20$ & 197 \\
\hline 382 & 0.21 & $00: 20$ & 191 \\
\hline 73 & 0.19 & 00:20 & 158 \\
\hline 168 & 0.51 & $00: 13$ & 157 \\
\hline 456 & 0.22 & $00: 16$ & 139 \\
\hline $238 \mathrm{z}$ & 0.45 & $00: 21$ & 132 \\
\hline 153 & 0.19 & 00:20 & 131 \\
\hline 322 & 0.10 & $00: 20$ & 110 \\
\hline 47 & 0.51 & 00:28 & 104 \\
\hline
\end{tabular}

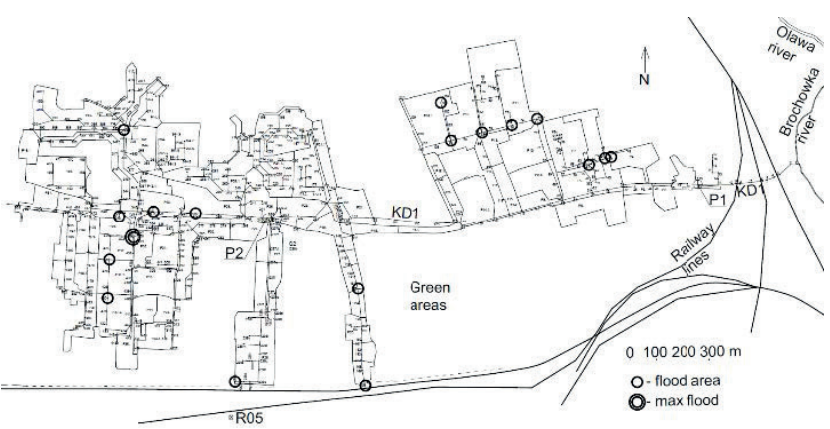

Fig. 5 Localization of floodings from stormwater drainage system for actual rainfall with $C=5$ years and $t=42$ minutes

Fig. 5 shows the locations of the outflows in the areas of the 17 nodes listed in Table 6.

The values of the criterial parameters are: $D O F=87 / 509$ $=0.17$ (for $N_{f}=87$ and $N=509$ ) and $S F V=3960 / 61.5=64.4$ $\mathrm{m}^{3} /$ ha (for $F V=3960 \mathrm{~m}^{3}$ and $S S=61.5 \mathrm{ha}$ ). According to the criterion in [15], the $S V O$ value $>13 \mathrm{~m}^{3} /$ ha indicates an urgent need to adapt the stormwater drainage system in the residential developments to climate changes.

\section{Conclusions}

The verification of the performance of the stormwater drainage system in Gaj and Tarnogaj residential developments in Wrocław has been presented. The verification was carried out using a calibrated hydrodynamic model of the system, created within the SWMM software. Two rainfalls: the Euler model rainfall type II with the frequency of 
occurrence in Wrocław $C=3$ years for the current drainage area supply conditions and an actual intensive rainfall with occurrence frequency $C=5$ years for the supply conditions in the future were used as the catchment load.

The degree of flooding (DOF) and the specific flood volume $(S F V)$ were adopted as the criteria for describing the system overload. In the case of the model rainfall (with frequency $C=3$ years) for $S F V=44.1 \mathrm{~m}^{3} /$ ha $>13 \mathrm{~m}^{3} /$ ha the system was found to be in need of upgrading. In the case of the actual rainfall (with frequency $C=5$ years) for $S F V=64.4 \mathrm{~m}^{3} / \mathrm{ha}>13 \mathrm{~m}^{3} /$ ha the system was also found in need of adapting to climate changes.

Thus the simulations showed that the investigated system does not meet the current standards. The causes of this should be sought in the too small diameters of the sewers and so in the insufficient hydraulic capacity of the sewerage system dimensioned in the past using methods which are inadequate today. In the unvaried (flat) terrain where the considered residential developments are located, outflows with a volume $>100 \mathrm{~m}^{3}$ in most cases occurred in the areas with the smallest sewer diameters: $0.30,0.40$ and $0.50 \mathrm{~m}$.

\section{References}

[1] Morales-Nápoles, O., Paprotny, D., Worm, D., Abspoel-Bukman, L., Courage, W. "Characterization of precipitation through copulas and expert judgement for risk assessment of infrastructure", ASCEASME Journal of Risk and Uncertainty in Engineering Systems, Part A: Civil Engineering, 3(4), 2017. https://doi.org/10.1061/AJRUA6.0000914

[2] Szpakowski, W., Szydłowski, M. "Evaluating the catastrophic rainfall of 14 July 2016 in the catchment basin of the urbanized Strzyza stream in Gdańsk, Poland", Polish Journal of Environmental Studies, 27(2), pp. 861-869, 2018.

https://doi.org/10.15244/pjoes/75962

[3] Ahmed, S., Tsanis, I. "Climate Change Impact on Design Storm and Performance of Urban Storm-Water Management System - A Case Study on West Central Mountain Drainage Area in Canada", Hydrology: Current Research, 7(1), 2016. https://doi.org/10.4172/2157-7587.1000229

[4] Dai, A. "Drought under global warming: a review", Wiley Interdisciplinary Reviews: Climate Change, 2(1), pp. 45-65, 2011. https://doi.org/10.1002/wcc.81

[5] Fleig, A. K., Tallaksen, L. M., James, P., Hisdal, H., Stahl, K. "Attribution of European precipitation and temperature trends to changes in synoptic circulation", Hydrology and Earth System Sciences, 19(7), pp. 3093-3107, 2015.

https://doi.org/10.5194/hess-19-3093-2015

[6] Kundzewicz, Z. W., Kanae, S., Seneviratne, S. I., Handmer, J., Nicholls, N. et al. "Flood risk and climate change: global and regional perspectives", Hydrological Sciences Journal, 59(1), pp. $1-28,2013$.

https://doi.org/10.1080/02626667.2013.857411
In the case when local system overloads are identified, further risk assessments are necessary [18]. They can be carried out on the basis of GIS or in-situ evaluations as part of an additional system performance simulation combined with a digital terrain model. This is recommended particularly when the criterial evaluation parameters (DOF and $S F V$ ) indicate an urgent need of adaptation [12]. A detailed analysis of the results of such simulations will enable one not only to demarcate the boundaries of floodplains, but also to specify the water depths and consequently, to determine the actual flooding hazard. In the hazardous areas, one should consider locating stormwater tanks or use other ways of relieving the network (e.g. drainage on individual premises) [19-23].

\section{Acknowledgement}

The work was realized within the allocation No. 0401/0006/17 awarded for Faculty of Environmental Engineering Wrocław University of Science and Technology by Ministry of Science and Higher Education in years 2017-2018.

[7] Saboia, M. A. M., Souza Filho, F. A., Araujo Junior, L. M., Silveira, C. S. "Climate changes impact estimation on urban drainage system located in low latitudes districts: a study case in Fortaleza-CE", Brazilian Journal of Water Resources, 22(21), 2017. https://doi.org/10.1590/2318-0331.011716074

[8] Schiermeier, Q. "Increased flood risk linked to global warming: likelihood of extreme rainfall may have been doubled by rising greenhouse-gas levels", Nature, 470, p. 316, 2011. https://doi.org/10.1038/470316a

[9] Walsh, K. J. E., McBride, J. L., Klotzbach, P. J., Balachandran, S., Camargo, S. J. et al. "Tropical cyclones and climate change", Wiley Interdisciplinary Reviews: Climate Change, 7(1), pp. 65-89, 2016. https://doi.org/10.1002/wcc.371

[10] Staufer, P., Leckebusch, G., Pinnekamp, J. "Die Ermittlung der relevanten Niederschlagscharakteristik für die Siedlungsentwässerung im Klimawandel" (The determination of the relevant precipitation characteristics for urban drainage in climate change), KA Korrespondenz Abwasser, Abfall, 57(12), pp. 1203-1208, 2010. (in German)

[11] Landesamt für Umwelt (LFU): "Bemessung von Misch- und Regenwasserkanälen. Teil 1: Klimawandel und möglicher Anpassungsbedarf" (Design of mixed and rainwater channels. Part 1: Climate change and possible adaptation needs), Referat 66 des Bayerischen Landesamtes für Umwelt, Merkblatt Nr. 4.3/3, 2009. (in German)

[12] Kotowski, A. "Podstawy bezpiecznego wymiarowania odwodnień terenów. Sieci kanalizacyjne (Tom I), Obiekty specjalne (Tom II)" (Basics of safe dimensioning of drainage areas. Sewer networks (Volume I), Special facilities (Volume II)), Seidel-Przywecki, Warsaw, Poland, 2015. (in Polish) 
[13] Szewrański, S., Chrusćinśki, J., Kazak, J., Swíader, M., TokarczykDorociak, K., Żmuda, R. "Pluvial Flood Risk Assessment Tool (PFRA) for rainwater management and adaptation to climate change in newly urbanised areas", Water, 10(4), 2018. https://doi.org/10.3390/w10040386

[14] Nowakowska, M., Kaźmierczak, B., Kotowski, A., Wartalska, K. "Identyfikacja, kalibracja i walidacja hydrodynamicznego modelu systemu odwadniającego tereny miejskie na przykładzie Wrocławia" (Identification, Calibration and Validation of Hydrodynamic Model of Urban Drainage System in the example of the City of Wroclaw), Ochrona Środowiska, 39(2), pp. 51-60, 2017. [in Polish]

[15] Siekmann, M., Pinnekamp, J. "Indicator based strategy to adapt urban drainage systems in regard to the consequences caused by climate change", presented at 12th International Conference on Urban Drainage, Porto Alegre, Brazil, Sept. 11-16, 2011.

[16] Kotowski, A., Kaźmierczak, B. "Probabilistic models of maximum precipitation for designing sewerage", Journal of Hydrometeorology, 14(6), pp. 1958-1965, 2013. https://doi.org/10.1175/JHM-D-13-01.1

[17] Nowakowska, M., Kotowski, A. " Metodyka i zasady modelowania odwodnień terenów zurbanizowanych" (Methodology and rules for modelling drainage of urban areas), Oficyna Wydawnicza Politechniki Wrocławskiej, Wroclaw, Poland, 2017. (in Polish)

[18] Schmitt, T. G. "Risikomanagement statt Sicherheitsversprechen" (Risk management instead of security promises), KA-Korrespondenz Abwasser, Abfall, 58(1), pp. 40-49, 2011. (in German)
[19] Beganskas, S., Fisher, A. T. "Coupling distributed stormwater collection and managed aquifer recharge: Field application and implications", Journal of Environmental Management, 200, pp. 366-379, 2017.

https://doi.org/10.1016/j.jenvman.2017.05.058

[20] Fratini, C. F., Geldof, G. D., Kluck, J., Mikkelsen, P. S. "Three Points Approach (3PA) for urban flood risk management: A tool to support climate change adaptation through transdisciplinarity and multifunctionality", Urban Water Journal, 9(5), pp. 317-331, 2012. https://doi.org/10.1080/1573062X.2012.668913

[21] Hostetler, M., Allen, W., Meurk, C. "Conserving urban biodiversity? Creating green infrastructure is only the first step", Landscape and Urban Planning, 100(4), pp. 369-371, 2011. https://doi.org/10.1016/j.landurbplan.2011.01.011

[22] Kirshen, P., Caputo, L., Vogel, R. M., Mathisen, P., Rosner, A., Renaud T. "Adapting Urban Infrastructure to Climate Change: A Drainage Case Study", Journal of Water Resources Planning and Management, 141(4), 2015. https://doi.org/10.1061/(ASCE)WR.1943-5452.0000443

[23] Stec, A. "Financial efficiency of rainwater utilization system in single-family house", presented at 9th Conference on Interdisciplinary Problems in Environmental Protection and Engineering EKODOK, Boguszow-Gorce, Poland, April 23-25, 2017. https://doi.org/10.1051/e3sconf/20171700086 